\title{
UNITED NATIONS OF RENDANG: MEME DALAM PERSPEKTIF STRUKTURALISME LÉVI-STRAUSS
}

\author{
Herry Nur Hidayat \\ Fakultas Ilmu Budaya, Universitas Andalas, Indonesia \\ herrynh@hum.unand.ac.id
}

DOI: 10.20884/1.jili.2019.10.2.2054

\begin{abstract}
Article History:
First Received:

ABSTRACT

$01 / / 11 / 2019$

This article analized meme United Nations of Rendang through Levi-Struss

Final Revision:

$23 / 12 / 2019$ structuralism perspective. In this case, social an culture seen as a structure which shows human unconsiuous to structuring a phenomenon.

Sign interrelation in United Nations of Rendang as a structure automatically

Available online: relate to the other meme which is another structure. Those sign convey to the

$30 / 12 / 2019$ surface structure and reveal the deep structure of this phenomenon. As a result, meme United Nations of Rendang shows rejection on Masterchef jury for the criticism on rendang as surface structure. This surface structure lead to awareness of same region country, awareness of western culinary domination, and a rejection for western culinary domination as deep structure.
\end{abstract}

Keywords: Meme; rendang; United Nations of Rendang; Levi-Strauss

\section{PENDAHULUAN}

Rendang adalah masakan daging sapi khas Indonesia yang diyakini berasal dari Minangkabau. Dengan bahan utama daging sapi, kelapa, dan berbagai bumbu rempah, proses memasak rendang membutuhkan waktu $6-7$ jam yang melewati tiga proses bentuk dan wujudnya yaitu gulai, kalio, dan rendang.

Rendang telah dinobatkan sebagai kuliner terlezat di dunia oleh CNN Go pada tahun 2011 lalu berdasarkan pilihan pembaca. Pada daftar 50 Masakan Terlezat Dunia, rendang menempati urutan 11. Dalam laporan survey tersebut dinyatakan rendang akan terasa lebih lezat jika dikonsumsi setelah didiamkan satu malam (CNNGo Staff, 2011; Dini, 2011).

Di sisi lain, proses memasak rendang yang demikian lama dan memiliki tujuan untuk memperpanjang waktu penyimpanan rendang hingga lama dianggap merugikan. Bahan dasar rendang yaitu daging dan kelapa mengandung protein dan lemak yang cukup tinggi. Akan tetapi, proses memasak dengan memanaskan dalam waktu lama dapat mengurangi kadar protein di dalamnya (Rini, Azima, Sayuti, \& Novelina, 2016). 
Sebagai kuliner khas Indonesia dengan kelezatan yang diakui dunia, rendang hingga saat ini diperebutkan kepemilikannya oleh empat negara yaitu Indonesia, Malaysia, Brunei, dan Singapura. Masing-masing mengklaim bahwa rendang adalah masakan khas negaranya untuk didaftarkan sebagai warisan budaya dunia ke UNESCO. Namun demikian, rendang telah didaftarkan sebagai warisan budaya dunia UNESCO oleh Provinsi Sumatera Barat pada tahun 2010 dengan nomor registrasi 776 (Pitakasari, 2012; Yudono, 2012) dan diperiksa kembali berkas pengajuannya pada Juli 2019 lalu (Ine, 2019; Yud, 2019).

Di balik perseteruan perebutan hak kepemilikan rendang, terjadi satu peristiwa yang sama sekali tidak diduga. Keempat negara tersebut, Indonesia, Malaysia, Brunei, dan Singapura bersatu juga karena rendang. Fenomena ini muncul di dunia maya (internet) melalui meme.

\section{Gambar 1. United Nations of Rendang}

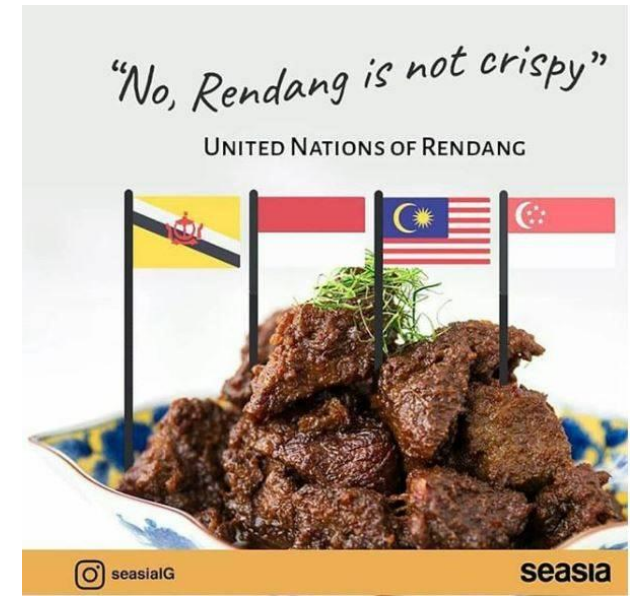

Gambar 1 di atas adalah meme dengan tagar yang sempat menjadi trending topic pada 2-3 April 2018 yaitu \#rendangcrispy. Bahkan, Perdana Menteri Malaysia Najib Razak juga bereaksi melalui akun Twitter-nya dalam peristiwa ini (Canoe, 2018). Tagar tersebut ternyata masih muncul hingga Juni 2018.

Kemunculan meme tersebut disebabkan peristiwa yang terjadi dalam sebuah kompetisi memasak Masterchef UK 2018. Saat itu, salah seorang kontestan keturunan Malaysia, Zaleha Kadir Olpin, dieliminasi ketika menghidangkan nasi lemak dengan rendang ayam. John Torode, salah seorang juri kompetisi itu, mengkritik masakan Zaleha bahwa rendang tidak seharusnya lembut. Juri lain, Gregg Wallace, juga mengkritik rendang Zaleha. "The skin isn't crispy," katanya. 
Peristiwa itu memicu reaksi warganet. Umumnya, warganet menyesalkan pernyataan juri tentang rendang yang seharusnya renyah (crispy). Saat itulah muncul beragam meme yang menyindir kritik juri Masterchef tentang rendang tersebut.

Jika dicermati, meme adalah sebuah bentuk komunikasi visual. Sarana komunikasi tersebut digunakan oleh warganet untuk menyuarakan ide dan gagasannya. Di sisi lain, warganet adalah sebuah kelompok sosial dengan sistem dan struktur sosial yang tidak jauh berbeda dengan kelompok sosial dunia luring. Makalah ini mencoba mengkaji meme United Nations of Rendang dengan perspektif strukturalisme Levi-Strauss.

Lévi-Strauss melahirkan konsep strukturalismenya sendiri. Hal yang perlu diperhatikan dalam strukturalisme adalah adanya perubahan pada struktur suatu benda atau aktivitas. Namun, perubahan tersebut adalah proses transformasi sehingga tidak mengubah seluruh struktur yang ada di dalamnya. Dalam proses ini hanya bagian-bagian tertentu saja yang berubah sementara elemen-elemen yang lama masih tetap. Prinsip dasar struktur dalam teori Lévi-Strauss adalah bahwa struktur sosial tidak berkaitan dengan realitas empiris, tetapi dengan model-model yang dibangun menurut realitasnya sendiri.

Ada berbagai macam asumsi yang mendasari pendekatan struktural dari Levi-Strauss. Salah satu di antaranya adalah bahwa fenomena kebudayaan dapat ditanggapi sebagai sistem atau rangkaian tanda. Tanda memiliki "makna" atau lebih tepat diberi "makna". Akan tetapi, makna ini berada pada tataran yang tidak disadari oleh pelakunya atau pemberi makna itu sendiri, dan tanda di sini dibedakan dengan simbol karena tanda tidak memiliki makna referensial atau makna acuan, sedang simbol memilikinya. Kalau makna suatu simbol adalah apa yang diacunya, referent-nya, maka makna tanda terletak pada relasinya dengan tanda-tanda yang lain. Model yang diambil di sini berasal dari linguistik, terutama dari fonologi struktural, yang dikembangkan oleh Roman Jakobson (Ahimsa-Putra, 1999).

Lebih lanjut, strukturalisme Lévi-Strauss secara implisit menganggap teks naratif, seperti misalnya mitos, sejajar dengan kalimat berdasarkan dua hal, yaitu: teks tersebut adalah satu kesatuan yang bermakna dan teks tersebut memberikan bukti bahwa dia diartikulasikan oleh bagian-bagian.

Dalam kajiannya terhadap kekerabatan, Strauss mengutip Troubetzkoy yang menyatakan bahwa kajian strukturalnya sebanding dengan kajian linguistik.

First, structural linguistics shifts from the study of conscious linguistic phenomena to study of their unconscious infrastructure; second, it does not treat terms as independent entities, taking instead as its basis of analysis the 
relations between terms; third, it introduces the concept of system (LéviStrauss, 1963).

Fenomena kebudayaan dapat dilihat sebagai suatu fenomena kebahasaan. Alasan yang paling mendasar, kenapa model pendekatan linguistik dapat digunakan untuk melihat fenomena kebudayaan, adalah karena: 1) bahasa yang digunakan oleh suatu masyarakat dianggap sebagai refleksi dari keseluruhan kebudayaan masyarakat yang bersangkutan. 2) karena bahasa bagian dari kebudayaan, atau bahasa merupakan salah satu unsur dari kebudayaan, dan 3) bahwa bahasa merupakan kondisi dari kebudayaan (Lévi-Strauss, 1963; Rahmawati, 2018; Taum, 2011).

Dalam hubungannya dengan peristiwa budaya, meme bisa dikatakan sebagai sebuah fenomena budaya yang menarik untuk dikaji. Meme adalah sebuah sarana komunikasi visual. Meskipun sebagian besar kita belum terbiasa dengan bentuk komunikasi tersebut, meme sangat terkenal dan banyak digunakan dalam media sosial di internet.

Tindak komunikasi dapat diartikan sebagai perpindahan, pergantian, atau berbagi informasi. Komunikasi berasal dari kata bahasa Latin communicare 'berbagi' atau 'berhubungan dengan' dan memiliki relasi dengan bahasa Inggris common, commune, dan community yang menyaran pada pengertian 'bersama'. Bagaimanapun, komunikasi mengandung beberapa komponen yang menyangkut pada who 'siapa', what 'apa', whom 'dengan siapa', channel 'sarana', dan effect 'dampak' (Cobley \& Schulz, 2013). Who adalah penutur, baik personal atau kelompok maupun institusi (Self, 2013), what merujuk pada isi pesan (Hample, 2013), whom menyaran pada audiens baik personal maupun kelompok (Shoemaker, Riccio, \& Johnson, 2013), channels adalah instrumen komunikasi baik material maupun nonmaterial (Boichini \& Lu, 2013), dan effects adalah refleksi kumulatif atau bertingkat yang muncul sebagai respons dan interpretasi audiens sesuai konteks komunikasi (Oliver, Woolley, \& Limperos, 2013). Meme merupakan pola "informasi budaya" yang mengalir dari satu gagasan ke gagasan lain dan terus bergerak sebagai refleksi perilaku sebuah kelompok sosial. Meme mengandung jejak perilaku, budaya kelompok, kebiasaan, fashion, arsitektur, gaya hidup, ikon, frasa, dan kesukaan (Knobel \& Lankshear, 2007).

\section{MATERIAL DAN METODE}

Objek material dalam artikel ini adalah meme dengan muatan tema rendang crispy. Meme yang menjadi pusat kajian adalah meme pada gambar 1 (United Nations of Rendang). Semua meme yang diperoleh kemudian dipilih dengan indikator yang menunjukkan kesamaan muatan dengan meme utama. Hal ini bisa diketahui dengan adanya tanda bendera empat negara yaitu Indonesia, Malaysia, Brunei, dan Singapura. Pemilihan meme objek kajian ini tidak berbatas 
pada waktu pengunggahan. Hal ini berarti meme terpilih tidak hanya berasal dari waktu unggah yang sama dengan meme utama.

Meme yang diperoleh kemudian dipilah dan dipilih berdasarkan muatan tema dan tampilan visual. Hal ini mempertimbangkan bahwa meme dalam penelitian ini dianggap sebagai sarana komunikasi sehingga harus mengandung daya tarik bagi pembaca. Pemilihan meme juga mempertimbangkan jumlah penyebarannya. Meme diperingkatkan berdasarkan jumlah penyebaran, maksudnya berapa kali dibagikan (share).

Meme terpilih kemudian dimaknai melalui tanda yang ada di dalamnya berdasarkan perspektif strukturalisme Levi-Strauss. Strukturalisme Lévi-Strauss berasumsi bahwa dalam diri manusia terdapat kemampuan dasar yang diwariskan secara genetis sehingga kemampuan ini ada pada semua manusia yaitu kemampuan untuk structuring, menyusun suatu struktur tertentu pada gejala yang dihadapinya. Mengkaji struktur berarti mengkaji aturan-aturan yang mengendap di dasar kesadaran manusia. Aturan-aturan yang tersembunyi secara diam-diam mengatur gerak manusia dalam berfikir, berbicara, berperilaku, dan berbudaya. Struktur tersebut dimaknai, kemudian ditangkap fungsinya melalui "tanda" yang ditempatkan dalam jaringan relasi dengan "tanda- tanda" yang lain (Salma, 2014).

Logika dasar atau nalar manusia menurut Lévi-Strauss mestinya terwujud dalam berbagai aktivitas kehidupan sehari-hari manusia. Nalar ini memang mengikuti struktur tertentu dalam bekerjanya, kita perlu menganalisis berbagai aktivitas yang merupakan perwujudan dari nalar tersebut. Fenomena-fenomena budaya pada dasarnya merupakan perwujudan dari nalar tersebut. Akan tetapi, tidak semua fenomena sama mudahnya untuk dibedah. Perlu dicari fenomena budaya yang sesuai untuk dikaji (Angelina, 2018).

Ada beberapa premis dalam pemikiran strukturalis. Pertama, ada pola pikir manusia yang berulang-ulang dalam tindakan-tindakan yang akhirnya memberi ciri khas pada suatu budaya tertentu. Kedua, struktur pikiran dalam suatu lingkungan budaya tertentu secara terpadu melatarbelakangi berbagai aspek kehidupan manusia dalam. Ketiga, pola pikiran disatu aspek kehidupan akan tercermin dalam aspek kehidupan lain (Sunliensyar, 2017).

Lebih lanjut Lévi-Straus (Lévi-Strauss, 1963) menyatakan, peneliti tidak bisa hanya menyatakan sebuah peristiwa selalu berujung pada rekonstruksi melalui sebuah hipotesis, melainkan paling tidak merujuk pada keaslian dan proses difusi dengan menunjukkan kemungkinan mana yang lebih tinggi. Sebuah kajian kebudayaan tidak hanya "berbicara" tentang pengalaman kesadaran dan ketaksadaran baik individu maupun kelompok tetapi memperoleh sesuatu atau menemukan sesuatu melalui modifikasi dan prediksi. 


\section{HASIL DAN PEMBAHASAN}

Sebelum membahas meme United Nations of Rendang, berikut ditampilkan tiga variasi meme yang senada dengan gambar 1. Ketiga meme berikut diasumsikan sebagai bangunan struktur yang masih berhubungan dengan objek utama kajian, yaitu meme pada gambar 1 .

Gambar 2. Infinity War of Rendang

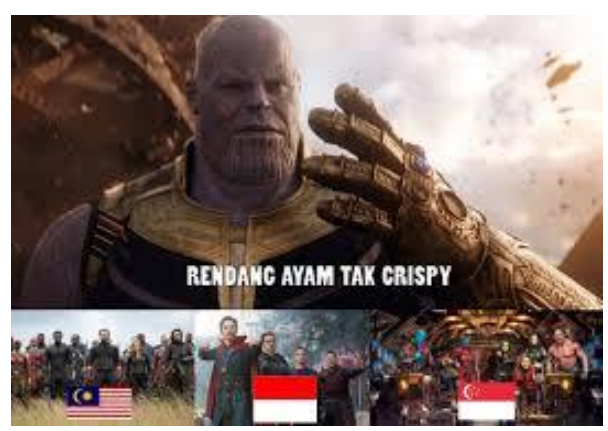

Gambar 3. Wrestle of Rendang

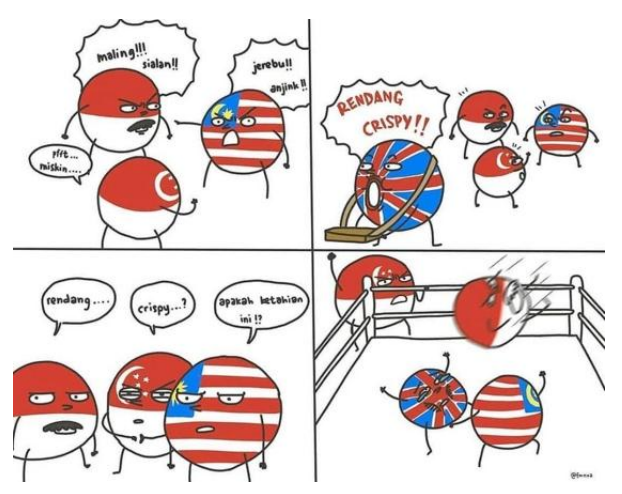

Gambar 4. Nusantara Damai

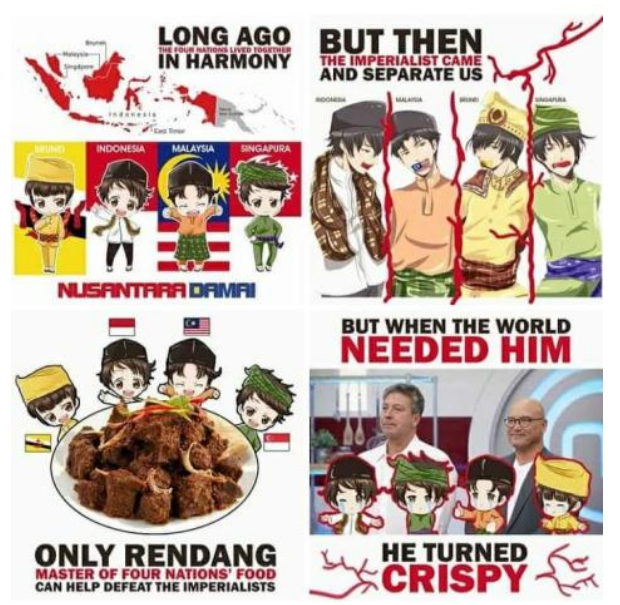


Seperti telah disebutkan pada bagian sebelumnya, struktur adalah sebuah rangkaian tanda, bukan simbol. Artinya tanda akan bermakna apabila memiliki relasi dengan tanda-tanda lain, bukan diinterpretasi layaknya simbol. Inilah bangunan struktur yang membentuk sistem.

Dalam konteks meme United Nations of Rendang, tanda-tanda yang terdapat dalam meme 2 - 4 memiliki hubungan dengan tanda-tanda dalam meme 1. Masing-masing tanda tidak akan memiliki makna tanpa saling dihubungkan. Kelompok kata United Nations of Rendang pada gambar 1 bisa dikatakan tidak bermakna sama sekali tanpa mengetahui konteks peristiwa yang juga merupakan tanda.

Dari gambar 1 - 4 dapat diperoleh tanda-tanda tekstual dan visual sebagai berikut.

Tabel 1. Tanda dalam Meme

\begin{tabular}{|c|c|}
\hline Gambar & Tanda \\
\hline 1 & $\begin{array}{l}\text { gambar rendang, bendera } 4 \text { negara (Indonesia, Malaysia, Brunei, } \\
\text { Singapura), kalimat "No, rendang is not crispy", kelompok kata United } \\
\text { Nations of Rendang, seasiaig. }\end{array}$ \\
\hline 2 & $\begin{array}{l}\text { bendera } 3 \text { negara (Indonesia, Malaysia, Singapura), Thanos, tiga kelompok } \\
\text { Avengers, kalimat "Rendang ayam tak krispi". }\end{array}$ \\
\hline 3 & $\begin{array}{l}\text { bendera } 4 \text { negara (Indonesia, Malaysia, Singapura, UK), kata "maling, } \\
\text { sialan, jerebu (asap), anjink, miskin, rendang crispy, rendang, crispy", } \\
\text { kalimat "apakah ketahian ini", karikatur tokoh gulat, arena gulat. }\end{array}$ \\
\hline 4 & $\begin{array}{l}\text { peta nusantara, bendera } 4 \text { negara (Indonesia, Malaysia, Brunei, Singapura), } \\
\text { karikatur tokoh masing-masing negara, dua orang juri Masterchef (Todore } \\
\text { dan Wallace), gambar rendang, kalimat "long ago the four nations lived } \\
\text { together in harmony", "but then the imperialist came and separate us", } \\
\text { "but when the world needed him", "he turned crispy", "only rendang } \\
\text { master of four nations' food can help defeat the imperialist". }\end{array}$ \\
\hline
\end{tabular}

Meme gambar 1 menimbulkan pertanyaan, mengapa muncul United Nations of Rendang? Mengapa ada pernyataan, No, rendang is not crispy? Pertanyaan-pertanyaan tersebut akan terjawab dengan menghubungkan tanda-tanda yang pada setiap meme dan kemudian dihubungkan dengan tanda-tanda pada meme lainnya.

Sebagai sebuah bangunan struktur, masing-masing tanda dalam setiap gambar tersebut tidak akan bermakna jika tidak saling dihubungkan. Gambar rendang dan kata crispy menjadi tanda yang menghubungkan keempat meme tersebut di samping bendera negara karena tandatanda tersebut muncul serentak. Jika masing-masing meme dimaknai melalui strukturnya masing-masing, pemaknaan masih akan belum lengkap. Meskipun dapat meraih struktur permukaan (surface structure), tanda-tanda yang ada dalam meme 1 masih belum cukup memadai untuk meraih makna struktur dalam (deep structure). Oleh karenanya, diperlukan 
tanda-tanda lain di luar struktur meme 1. Namun demikian, tanda dari luar dipilih dari struktur yang tidak jauh berbeda konteksnya, yaitu rendang, empat negara di Asia Tenggara (Indonesia, Malaysia, Brunei, dan Singapura), serta kata cripsy. Dalam hal ini, ditemukan meme 2 - 4 tersebut di atas.

Melalui tanda yang sederhana, meme 2 menunjukkan tanda perseteruan tiga negara (Indonesia, Malaysia, Singapura) yang digambarkan sebagai kelompok Avengers melawan Thanos. Namun, makna tanda yang muncul dalam bentuk tokoh-tokoh Avengers dan Thanos hanya bisa dimaknai apabila pembaca meme telah mengenal dan mengetahui cerita Marvel Cinematic Universe ("Marvel Cinematic Universe," n.d.; "Marvel Cinematic Universe," 2019). Nampaknya, pencipta menganalogikan cerita Marvel ke dalam meme kreasinya. Di samping itu, tanda pada kalimat "rendang ayam tak crispy" juga bisa dimaknai setelah pembaca mengetahui konteks peristiwa yang terjadi pada Masterchef UK 2018. Akhirnya, kalimat bernada kritik ini bisa dimaknai sebagai pemersatu Avengers untuk melawan Thanos.

\section{Gambar 5. Strukturasi Meme 2}

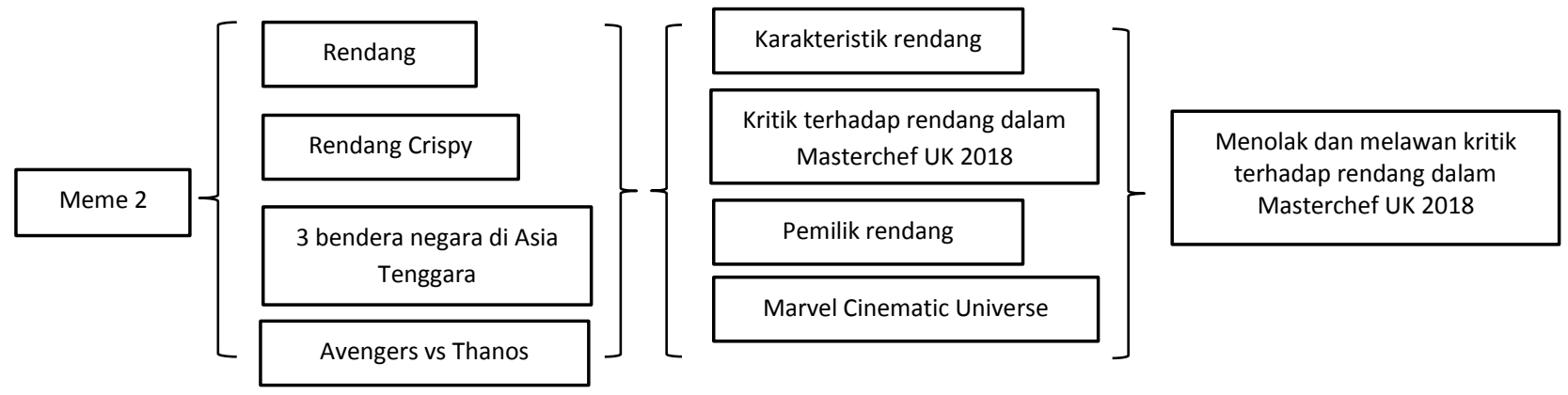

Pada meme 3, kata berkesan makian, "maling, sialan, jerebu (asap), anjink, miskin" menandakan adanya perseteruan atau pertengkaran pada masing-masing tokoh yang juga ditandai bendera negara. Relasi antara tanda tersebut dapat dimaknai adanya perseteruan antara negara Indonesia, Malaysia, dan Singapura. Indonesia menyebut Malaysia “maling”, Malaysia mengeluhkan "jerebu" sehingga memaki dengan kata "anjink" pada Indonesia, sementara Singapura menyebut Indonesia dan Malaysia "miskin.

Hubungan semua tanda tersebut akan semakin jelas jika mengetahui konteks peristiwa yang melatari munculnya kata-kata makian tersebut. Konteks peristiwa kata "maling" berelasi dengan peristiwa klaim beberapa tradisi kesenian Indonesia oleh Malaysia, perebutan kepemilikan beberapa pulau, serta pencurian ikan di wilayah perairan Indonesia oleh beberapa nelayan yang menggunakan kapal berbendera Malaysia. Di sisi lain, kata "jerebu" dan "anjink" yang muncul pada tokoh berbendera Malaysia kepada Indonesia berhubungan erat dengan 
peristiwa kabut asap oleh karena pembakaran lahan di beberapa wilayah di Indonesia. Dalam hal ini, kerugian yang diakibatkan kabut asap tersebut sangat besar sehingga muncullah kata makian "anjink".

Munculnya tokoh penjaja makan berbendera Inggris (UK) yang melontarkan seruan rendang crispy!! dengan segera menghentikan pertengkaran ketiga tokoh sebelumnya. Pertanyaan bernada heran muncul dari mereka yang jika dirangkai menjadi kalimat, Rendang crispy? Apakah ketahian ini? (Ketahian adalah bahasa Melayu yang berarti keberanian, terlalu berani). Kalimat tersebut dapat diartikan sebagai pertanyaan kepada tokoh berbendera Inggris, Rendang crispy? Kamu menantang, ya? Tentu saja pemaknaan tanda tersebut juga berhubungan struktur tanda lain yang berada di luar struktur meme tersebut yaitu gulat bebas. Struktur gulat bebas tersebut muncul dalam bentuk tanda visualisasi tokoh, arena gulat, dan pertarungan tag team antara tokoh berbendera Indonesia, Malaysia, dan Singapura melawan tokoh berbendera Inggris.

\section{Gambar 6. Strukturasi Meme 3}

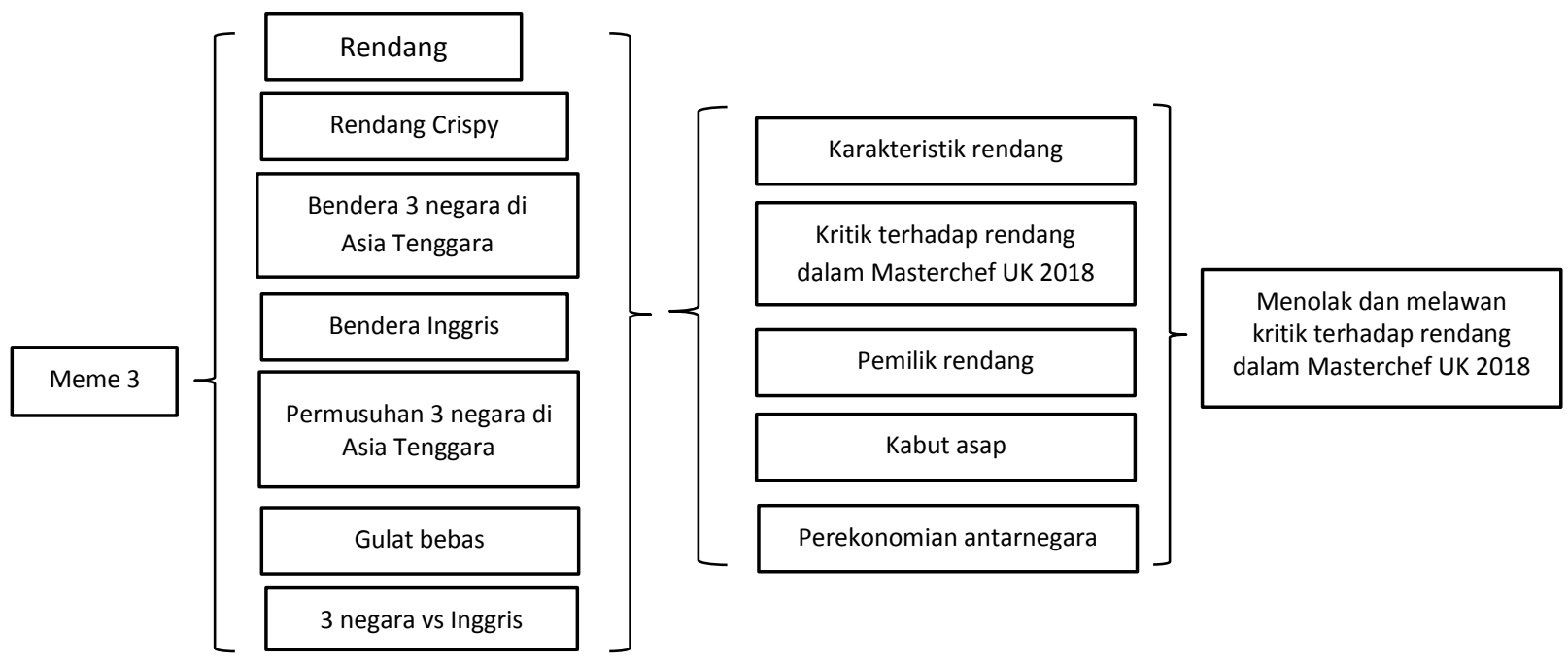

Tanda perseteruan dan permusuhan dalam meme 2 dan 3 juga bisa dihubungkan dengan tanda pada gambar 4 melalui kalimat but then the imperialist came and separate us. Berbeda dengan meme-meme sebelumnya, meme 4 mengadopsi bentuk komik dengan empat panel dalam satu frame. Pembacaannya bisa diurutkan dengan panel 1 kiri atas, panel 2 kanan atas, panel 3 kanan bawah, dan panel 4 kiri bawah. Sebagai sebuah tanda, panel $1-4$ menunjukkan sebuah alur peristiwa yang jelas.

Karakter yang ditampilkan dalam tiap panel juga menunjukkan latar suasana yang cukup jelas. Pada panel 1, kalimat long ago the four nations lived together in harmony memiliki relasi 
atau hubungan dengan pelukisan karakter. Keharmonisan keempat negara ditandai dengan visualisasi karakter yang ceria, sedangkan kalimat but then the imperialist came and separate us berhubungan juga dengan visualisasi karakter pada panel 2. Sementara itu, pemaknaan tanda pada panel 3 memerlukan tanda yang terdapat pada panel 4 dan struktur peristiwa yang menjadi konteks meme secara keseluruhan. Kalimat but when the world needed him dan he turned crispy tidak bisa serta merta dimaknai melalui tanda-tanda yang terdapat di dalamnya. Kata world, him, dan he belum bisa dimaknai jika tidak melalui tanda-tanda pada panel 4. Kalimat only rendang master of four nations' food can help defeat the imperialist menjadi penanda bahwa kata world berelasi dengan food dan kata him dan he berelasi dengan rendang. Secara bebas, alur cerita pada meme 4 bisa diterjemahkan: Dahulu kala, empat negara (Indonesia, Malaysia, Brunei, dan Singapura) ini hidup rukun dan damai. "Namun, imperialis datang memecah belah kami. Dan saat dunia (kuliner) membutuhkannya (rendang), dia (rendang) diubah menjadi crispy. Hanya rendang, jawara masakan empat negara yang dapat mengalahkan imperialis”.

\section{Gambar 7. Strukturasi Meme 4}

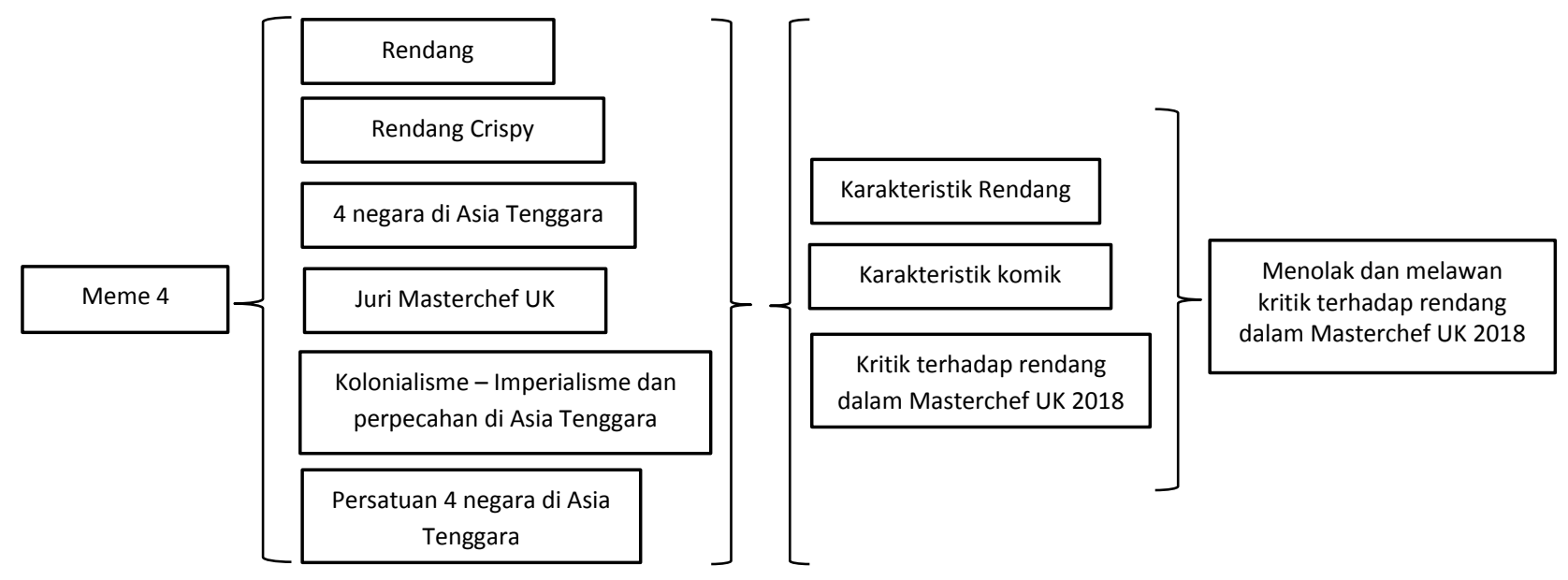

Jadi jelas, meme pada gambar 2, 3, dan 4 mengandung tanda permusuhan, perseteruan, dan pertarungan. Tokoh Thanos dari cerita Marvel Infinity War pada gambar 2, tokoh berbendera UK pada gambar 3 yang menjadi lawan tiga negara (Indonesia, Malaysia, dan Singapura), serta visualisasi dua juri Masterchef UK yang digambarkan juga sebagai imperialis adalah pihak yang berlawanan dengan empat negara (Indonesia, Malaysia, Brunei, dan Singapura ) dalam ketiga meme tersebut. Dapat diketahui selanjutnya bahwa perlawanan itu dipicu oleh rendang crispy. Di sisi lain, penyebab persatuan negara-negara di Asia Tenggara itu juga rendang crispy. Perasaan kepemilikan terhadap rendang seolah menjadi juru damai keempat negara. 
Sampai di sini, masing-masing tanda telah dihubungkan, tetapi belum juga diperoleh makna yang utuh. Sebuah tanda tidak dapat dimaknai secara utuh tanpa memahami konteks tanda tersebut. Keempat meme di atas masih berhubungan dengan tanda di luar meme itu sendiri. Dalam hal ini adalah peristiwa dieliminasinya salah satu kontestan Masterchef UK 2018, Zaleha Kadir Olpin, oleh karena juri, John Todore dan Greg Wallace, yang tidak menerima dan mengkritik hidangan rendang ayam yang disajikan. Salah satu juri menyebut rendangnya tidak crispy. Di samping itu, makna tanda perseteruan antara tokoh Thanos dan Avengers pada gambar 2 juga tidak dapat diraih tanpa mengetahui konteks siapa Thanos dan Avengers. Tanda-tanda pada gambar 3 juga tidak akan dapat dimaknai jika tidak mengetahui gambaran dan suasana pertarungan gulat bebas.

Dengan dihubungkannya tanda-tanda yang ada dalam keempat meme tersebut dengan konteks peristiwa yang juga dianggap sebagai tanda, makna meme gambar 1 dapat diraih dan diperoleh secara utuh. United Nations of Rendang muncul sebagai bentuk kritik dan perlawanan terhadap kritik juru Masterchef UK 2018 atas rendang yang dianggap tidak crispy (renyah). Sebagai negara asal kuliner rendang, Indonesia, Malaysia, Brunei, dan Singapura merasa perlu meluruskan kritik tersebut. Di samping itu, oposisi dalam meme gambar 1 dapat juga ditemukan setelah menghubungkan konteks peristiwa di balik munculnya meme tersebut. Secara tidak langsung, United Nations of Rendang beroposisi dengan kalimat No, Rendang is not crispy yang secara implisit merujuk pada kritik juri Masterchef.

\section{Gambar 8. Strukturasi Meme 1}

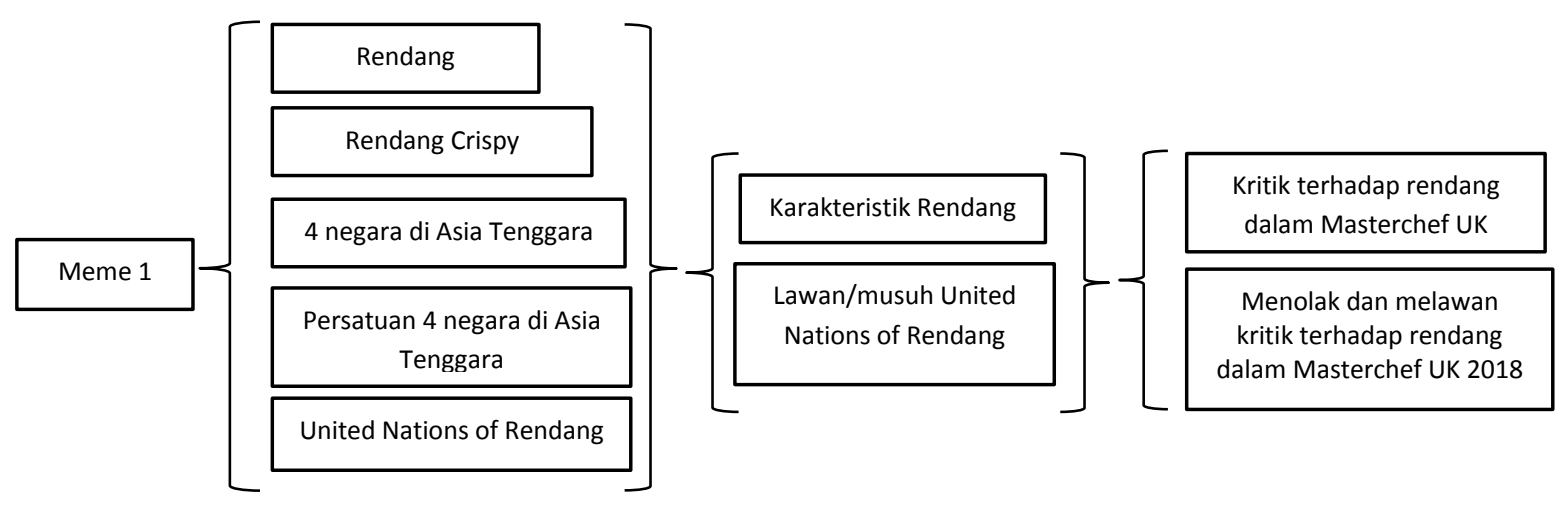

Sebagai sebuah strukturasi, secara singkat tanda-tanda dalam keempat meme tersebut dapat diperoleh sebagai berikut (tabel 2). 
Tabel 2. Sruktur dalam Meme United Nations of Rendang

\begin{tabular}{|c|c|}
\hline Struktur & Muatan \\
\hline 1 & Rendang crispy \\
\hline 2 & Pengetahuan tentang karakteristik rendang \\
\hline 3 & Perseteruan empat negara Asia Tenggara \\
\hline 4 & $\begin{array}{l}\text { Perebutan kepemilikan rendang oleh } 4 \text { negara Asia Tenggara } \\
\text { (Indonesia, Malaysia, Brunei, Singapura }\end{array}$ \\
\hline 5 & Klaim warisan budaya Indonesia oleh Malaysia \\
\hline 6 & Perebutan wilayah Indonesia - Malaysia \\
\hline 7 & Tingkat kesejahteraan warga negara \\
\hline 8 & Kebakaran lahan penyebab kabut asap (jerebu) \\
\hline 9 & Dipecah belah imperialis \\
\hline 10 & Persatuan 4 negara membentuk United Nations of Rendang \\
\hline 11 & Pertarungan melawan Thanos \\
\hline 12 & Marvel Cinematic Universe \\
\hline 13 & Pertarungan gulat bebas melawan tokoh berbendera Inggris \\
\hline 14 & Gulat bebas \\
\hline 15 & Perlawanan terhadap imperialis \\
\hline 16 & Warganet \\
\hline 17 & Kesadaran negara serumpun \\
\hline 18 & Kesadaran kepemilikan rendang \\
\hline 19 & Kesadaran negara pernah dijajah \\
\hline 20 & Perlawanan dominasi kuliner Barat \\
\hline 21 & Masterchef UK 2018 \\
\hline 22 & $\begin{array}{l}\text { Dieliminasinya Zaleha pada kompetisi Masterchef UK } 2018 \text { karena } \\
\text { kritik juri terhadap rendang yang dihidangkannya }\end{array}$ \\
\hline
\end{tabular}

Sebagai sebuah kelompok sosial, warganet memiliki bangunan sistem struktur dan etika tersendiri. Kesadaran akan perseteruan antarnegara muncul dalam meme di atas. Namun, kesadaran akan perlunya persatuan dalam menghadapi ancaman juga menjadi kekhasan 
warganet. Melalui meme, warganet berkomunikasi dan menyampaikan ide dan gagasannya. Perlawanan juga dilakukan melalui meme.

Kata "imperialist" pada meme gambar 4 menunjukkan tanda kesadaran dan perlawanan terhadap dominasi kuliner Barat. Kompetisi kuliner di beberapa negara Asia, khususnya Asia Tenggara, lebih mengedepankan kuliner ala Barat. Kesan perlawanan ini juga muncul melalui tanda-tanda dalam meme.

Gambar 9. Fried Chicken

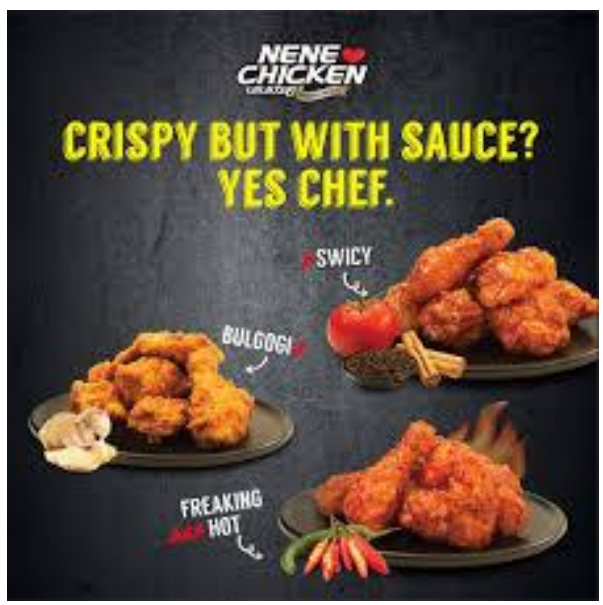

\section{Gambar 10. Chicken Burger}

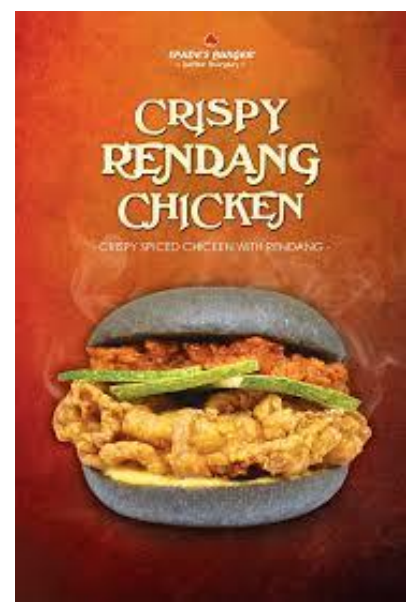

Gambar 6 dan 7 di atas adalah tanda yang masih berhubungan dengan tagar \#rendangcrispy. Meme 6 dan 7 tersebut adalah tanda penunjukkan kuliner sebenarnya yang dimaksud oleh juri Masterchef. Warganet menganggap juri tidak mengenal karakteristik rendang yang original. Warganet menganggap juri hanya mengetahui kuliner ala Barat yang ditandai dengan gambar ayam goreng dan burger.

Hasil analisis menunjukkan bahwa tanda-tanda yang merupakan struktur permukaan (surface structure) dalam meme 1 pada akhirnya menghubungkannya dengan tanda-tanda lain, baik di dalam maupun dari luar meme 1 tersebut. United Nations of Rendang bukan hanya menunjukkan penyatuan dan persatuan negara "pemilik" rendang, tetapi juga berhubungan dengan tanda lain yang juga merupakan struktur yang berbeda. Hal ini sesuai dengan yang dinyatakan Lévi-Strauss (Salma, 2014) bahwa dalam diri manusia terdapat kemampuan dasar yang diwariskan secara genetis sehingga kemampuan ini ada pada semua manusia yaitu kemampuan untuk structuring, menyusun suatu struktur tertentu pada gejala yang dihadapinya.

Meme United Nations of Rendang menunjukkan bahwa sebuah struktur akan membentuk dan membangun struktur baru sesuai dengan fenomena yang dialami manusia. Demikian sebaliknya, sebuah tanda akan menuntun pada tanda lain yang merupakan struktur yang berbeda. Inilah yang disebut dengan struktur dalam (deep structure) sebuah fenomena sosial atau budaya. 
Berbagai variasi meme dengan tema rendang crispy ini juga menunjukkan bahwa fenomena sosial budaya bisa dianalogikan sebagai tindak kebahasaan. Tema rendang crispy dalam meme adalah langue dan variasi meme adalah parole. Kesamaan ide dan gagasan dituangkan dalam bentuk meme dengan bentuk, model, dan gaya penyampaian yang berbeda bergantung pada pengetahuan penciptanya.

\section{SIMPULAN}

Peristiwa dieliminasinya Zaleha dalam kompetisi memasak Masterchef UK 2018 lalu telah menunjukkan warganet sebagai sebuah kekuatan (di dunia daring) yang mampu menekan kekuatan di dunia nyata (luring). Relasi-relasi yang dibangun oleh warganet melalui dunia daring dalam peristiwa itu menjembatani jurang pemisah antara empat negara, Indonesia, Malaysia, Singapura, dan Brunei.

Rendang dalam hal ini menjadi kunci dan penghubung antarrelasi tersebut. Persatuan pengetahuan, pengalaman, gagasan, dan ide tentang rendang menjadi sarana komunikasi yang efektif dalam hubungan relasi tersebut. Rendang seolah menjadi sarana negosiasi dan transaksi keempat negara tersebut untuk meruntuhkan dominasi "kolonialisasi" kuliner.

Melalui meme United Nations of Rendang dapat pula diketauhi ketaksadaran yang membangun sebuah gagasan dan ide empat negara bersatu. Kesadaran negara serumpun dan kesadaran akan dominasi kuliner Barat dewasa ini membawa sebuah kelompok sosial melakukan gerakan dan perlawanan dengan berbagai cara.

Di samping itu, dunia daring memiliki sebuah sistem dan struktur yang dibangun oleh warganya (warganet). Dunia tersebut memiliki hukum, aturan, dan etika yang terstruktur sebagai wujud sebuah budaya yang tidak jarang begitu kuat mempengaruhi dunia luring.

\section{DAFTAR PUSTAKA}

Ahimsa-Putra, H. S. (1999). STRUKTURALISME LEVI-STRAUSS UNTUK ARKEOLOGI

SEMIOTIK'. Jurnal Humaniora, 11(3), 5-14. https://doi.org/10.22146/jh.v11i3.665

Angelina, D. (2018). MITOS RADHIN SAGHÂRÂ DALAM KAJIAN STRUKTURALISME

LEVI-STRAUSS. SEMIOTIKA: Jurnal Ilmu Sastra Dan Linguistik, 18(2), 41.

https://doi.org/10.19184/semiotika.v18i2.6462

Boichini, D., \& Lu, A. S. (2013). Channel. In P. Cobley \& P. J. Schulz (Eds.), Theories and Models of Communication. Berlin - Boston: Walter de Gruyter.

Canoe. (2018, April 3). Should chicken in rendang curry be crispy? Masterchef U.K. sparks 
debate | Canoe. Retrieved from https://canoe.com/life/food/should-chicken-in-rendang-curry-becrispy-masterchef-u-k-sparks-debate

CNNGo Staff. (2011, July 21). World's 50 most delicious foods \#2 | CNNGo.com. Retrieved from

https://web.archive.org/web/20111005232750/http://www.cnngo.com/explorations/eat/worlds50-most-delicious-foods-067535? page $=0,1$

Cobley, P., \& Schulz, P. J. (Eds.). (2013). Theories and Models of Communication. Berlin Boston: Walter de Gruyter.

Dini. (2011, September 10). Rendang, Hidangan Terlezat di Dunia. Retrieved from https://lifestyle.kompas.com/read/2011/09/10/20395488/Rendang.Hidangan.Terlezat.di.Dunia Hample, D. (2013). What. In P. Cobley \& P. J. Schulz (Eds.), Theories and Models of Communication. Berlin - Boston: Walter de Gruyter.

Ine. (2019, July 8). West Sumatra proposes "rendang" as world heritage to UNESCO. Retrieved from https://en.antaranews.com/news/128601/west-sumatra-proposes-rendang-as-worldheritage-to-unesco

Knobel, M., \& Lankshear, C. (2007). Online Memes, Affinities, and Cultural Production. In K. Michele \& C. Lankshear (Eds.), A New Literacies Sampler. New York - Washington, D.C./Baltimore - Bern Frankfurt am Main - Berlin - Brussels - Vienna - Oxford: Peter Lang. Lévi-Strauss, C. (1963). Structural Anthropology. (C. Jacobson \& B. G. Schoepf, Eds.). New York: Basic Books.

Marvel Cinematic Universe. (n.d.). Retrieved from

https://marvelcinematicuniverse.fandom.com/wiki/Marvel_Cinematic_Universe

Marvel Cinematic Universe. (2019). Retrieved from

https://en.wikipedia.org/wiki/Marvel_Cinematic_Universe

Oliver, M. B., Woolley, J. K., \& Limperos, A. M. (2013). Effect. In P. Cobley \& P. J. Schulz (Eds.), Theories and Models of Communication. Berlin - Boston: Walter de Gruyter.

Pitakasari, A. R. (2012, June 26). Rendang Sudah Didaftarkan ke UNESCO, “Malaysia Silakan Klaim.” Retrieved from https://www.republika.co.id/berita/senggang/senibudaya/12/06/26/m67zs5-rendang-sudah-didaftarkan-ke-unesco-malaysia-silakan-klaim Rahmawati, I. (2018). PEMIKIRAN STRUKTURALISME LEVI-STRAUSS. Tamaddun: 
Jurnal Kebudayaan Dan Sastra Islam, 18(1), 93-103.

https://doi.org/10.19109/tamaddun.v18i1.2317

Rini, Azima, F., Sayuti, K., \& Novelina. (2016). The Evaluation of Nutritional Value of Rendang Minangkabau. Agriculture and Agricultural Science Procedia, 9, 335-341.

https://doi.org/10.1016/J.AASPRO.2016.02.146

Salma, I. R. (2014). BATIK KREATIF AMRI YAHYA DALAM PERSPEKTIF

STRUKTURALISME LEVI-STRAUSS. Dinamika Kerajinan Dan Batik, 31(1). Retrieved from https://intranet.batik.go.id/file_lampiran/media/5._BATIK_KREATIF_AMRI_YAHYA_DALA M_PERSPEKTIF_STRUKTURALISME_LEVI-STRAUSS_-_Irfa'ina_Rohana_Salma_pdf Self, C. C. (2013). Who. In P. Cobley \& P. J. Schulz (Eds.), Theories and Models of Communication. Berlin - Boston: Walter de Gruyter.

Shoemaker, P. J., Riccio, J., \& Johnson, P. R. (2013). Whom. In P. Cobley \& P. J. Schulz (Eds.), Theories and Models of Communication. Berlin - Boston: Walter de Gruyter.

Sunliensyar, H. H. (2017). MENGGALI MAKNA MOTIF HIAS BEJANA PERUNGGU NUSANTARA: PENDEKATAN STRUKTURALISME LEVI-STRAUSS. Berkala Arkeologi, 37(1), 51-68. https://doi.org/10.30883/jba.v37i1.71

Taum, Y. Y. (2011). TEORI-TEORI ANALISIS SASTRA LISAN: STRUKTURALISME LEVI-STRAUSS. In Studi Sastra Lisan: Sejarah, Teori, Metode dan Pendekatan, Disertai dengan Contoh Penerapan (pp. 159-193). Yogyakarta: Penerbit Lamalera.

Yud. (2019, July 8). Sumbar Usulkan Rendang Jadi Warisan Dunia UNESCO. Retrieved from https://www.beritasatu.com/gaya-hidup/563289/sumbar-usulkan-rendang-jadi-warisan-duniaunesco

Yudono, J. (2012, June 27). 12 Budaya Nasional Sudah Diakui UNESCO. Retrieved from https://sains.kompas.com/read/2012/06/27/12254076/12.budaya.nasional.sudah.diakui.unesco 